of epigenetic contributions to ageing, development and disease, and responses to environmental exposures; the discovery of new epigenetic targets; and the development of technology, data analysis and computational infrastructure. The deadline for proposals is March, and fiveyear funding will begin next autumn.

\section{San Francisco gets a green natural history museum}

Last week, the California Academy of Sciences received the keys to its new environmentally friendly headquarters. The building sits on the site of its historic home, which was damaged during the 1989 Loma Prieta earthquake. Nestled in scenic Golden Gate Park, in environmentally conscious San Francisco, it is in an ideal location for an ecologically inspired museum.

The new \$484-million building was designed by architect Renzo Piano and incorporates so many green design features,

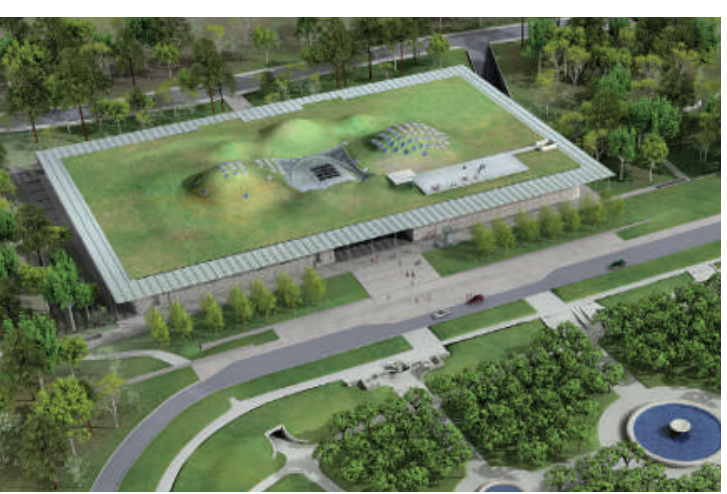

Going green: a model of the California Academy of Sciences' new home.

including a green roof (pictured above) and insulation made from recycled blue jeans, that it beats the energy-use standards set by the US Department of Energy by $30 \%$. Even the steel and rubble from the old headquarters were recycled to make other buildings and new roads.

It is also expected to be the first museum to earn the highest stamp of approval from the US Green Building Council's Leadership in Energy and Environmental Design Green Building Rating System - a nationally accepted set of benchmarks for green design.

\section{Partnership paves way for global carbon market}

A coalition of countries, US states and Canadian provinces formed a partnership last week to promote the establishment of a global carbon-trading market.

Officials billed the International Carbon Action Partnership as a central repository for sharing information among various nations and coalitions that are adopting market-based regulations for greenhouse gases. The goal is to align the development of independent markets so that they can serve as the foundation for an integrated global market.

The European Union has a functioning carbon-trading market under the Kyoto Protocol, and the Chicago Climate Exchange, a smaller market based on voluntary emissions reductions, is operational in the United States.

The new coalition includes nine members of the European Union, the European Commission, ten US states and two Canadian provinces that are organizing two regional greenhouse-gas markets. New Zealand and Norway are also founding members.

\section{White males maintain pole positions in US science}

If you are studying science in the United States, the chances are that your mentor is a white male. And although more underrepresented minorities and women are earning degrees, fields such as chemistry and mathematics are among the worst in helping them make the leap to faculty positions, according to a report led by Donna Nelson, a chemist at the University of Oklahoma in Norman (see http://tinyurl.com/yqwjyq).

The department-by-department breakdown of the 100 top-spending science and engineering departments shows that some fields are more inclusive than others. In sociology, one of the best disciplines at training minorities, the percentage of blacks, Hispanics and Native Americans earning PhDs equals the percentage of assistant professors from those groups in the top 50 departments surveyed. In chemistry, by contrast, minorities earn $8.5 \%$ of $\mathrm{PhDs}$ - but just $3.7 \%$ of all professorships and $4.7 \%$ of assistant professorships.

For women, children and lower selfconfidence may help to explain the gap, suggests a separate survey by the US National Institutes of Health of more than 1,300 postdocs (E. D. Martinez et al. EMBO Rep. 8, 977-981; 2007). Women are more likely than men to sacrifice their careers for kids, the survey found, and $60 \%$ of males versus $40 \%$ of females felt confident that they would find a faculty job after completing their postdoc.

\section{Correction}

The News Feature 'Space invaders' (Nature 448, 746-748; 2007) stated that Omar Yaghi was the first to design a metal-organic framework (MOF) in 1998. But in the early 1990s, before the term MOF was coined, a similarly open three-dimensional polymeric network structure linking organic ligands and metal centres had been reported (B. F. Hoskins and R. Robson J. Am. Chem. Soc. 112, 1546-1554; 1990). 